\title{
Small colony variant-producing $S$ aureus prosthesis joint infection highlighted by sonication and treated with prolonged high doses of daptomycin
}

\author{
Camille Piffaut, ${ }_{1}^{1}$ Sébastien Lustig, ${ }^{2,3,4}$ Frédéric Laurent, ${ }^{1,2,4,5,6}$ Christian Chidiac, 2,4,5,7 \\ Tristan Ferry, $2,4,5,6,7$ on behalf of the Lyon BJI Study Group
}

${ }^{1}$ Laboratoire de Bactériologie, Hôpital de la Croix-Rousse, Hospices Civils de Lyon, Lyon, France

${ }^{2}$ Université Claude Bernard Lyon 1, Lyon, France ${ }^{3}$ Service de Chirurgie Orthopédique, Centre Albert Trillat, Hôpital de la CroixRousse, Hospices Civils de Lyon, Lyon, France

${ }^{4}$ Centre Interrégional de Référence Rhône-Alpes Auvergne des Infections Ostéoarticulaires complexes, Lyon, France

${ }^{5}$ Centre International de Recherche en Infectiologie, CIRI, Inserm U1111, CNRS UMR5308, ENS de lyon, UCBL1, Lyon, France ${ }^{6}$ Centre National de Référence des Staphylocoques, Lyon, France

${ }^{7}$ Service de Maladies Infectieuses et Tropicales, Hôpital de la Croix-Rousse Hospices Civils de Lyon, Lyon, France

\section{Correspondence to} Dr Tristan Ferry,

tristan.ferry@univ-lyon1.fr

\footnotetext{
To cite: Piffaut $C$, Lustig $S$ Laurent $F$, et al. BMJ Case Rep Published online: [please include Day Month Yearl doi:10.1136/bcr-2013008637
}

\section{DESCRIPTION}

An 80 -year-old woman with a history of $\beta$-lactam allergy was admitted for chronic knee prosthesis joint infection (PJI) (figure 1A). The prosthesis was removed and sonicated as previously described $(400 \mathrm{ml}$ of Ringer solution was added in a sterile box containing the explanted prosthesis, vortexing was performed before and after sonication in ultrasound bath, and then $100 \mu \mathrm{l}$ of sonicate fluid was plated onto aerobic and anaerobic medium and broth). ${ }^{1}$ All peroperative samples revealed methicillin-susceptible Staphylococcus aureus in cultures, whereas the sonicate fluid culture yielded additional $S$ aureus small colony variant phenotype (SCV) (figure 1B). Vancomycin $(1 \mathrm{~g} /$ day intravenously) followed by rifampin (1200 mg/day orally) were started. As a rash with eosinophilia occurred, vancomycin and rifampin were switched to daptomycin $850 \mathrm{mg} /$ day $(9 \mathrm{mg} / \mathrm{kg} /$ day $)$. Reimplantation, performed after a 6-week interval, did not reveal any bacterial growth in culture. Daptomycin was continued for a total duration of 3 months, with perfect clinical and biological tolerance. At 1-year follow-up, clinical and radiological outcomes were favourable (figure 1C).

$S$ aureus, one of the most frequent aetiological agent of PJI, is associated with a high rate of relapse, partly explained by its capacity to produce biofilm and to convert into SCV, which is a slow-growing phenotype associated with intracellular persistence. ${ }^{2}$
Our case highlights that (1) sonication should help to isolate these phenotypic variants, actually underestimated due to fastidious growth requirements; (2) prolonged high dose $(\geq 8 \mathrm{mg} / \mathrm{kg} / \mathrm{J})$ of daptomycin (considered as an alternative for the treatment of $S$ aureus $\mathrm{PJI}$ at the standard dose of $6 \mathrm{mg} / \mathrm{kg} / \mathrm{J}^{3}$ ) might be efficient in patients with chronic PJI due to SCV expressing $S$ aureus. In fact, as it was demonstrated for rifampin (compromised in our case), recent studies pinpointed the antibiofilm activity of daptomycin. Its antimicrobial activity against SCV remained to be investigated.

\section{Learning points}

- Sonication may help to show small colony variant phenotype in Staphylococcus aureus chronic prosthesis joint infection.

- Daptomycin could be used for the treatment of $S$ aureus chronic prosthesis joint infection.

Acknowledgements We acknowledge Dr Franck Trouillet who participated to the patient care and all our colleagues from the Lyon Bone and Joint Infection study Group: Physicians-Tristan Ferry, Thomas Perpoint, André Boibieux, François Biron, Florence Ader, Anissa Bouaziz, Judith Karsenty, Fatiha Daoud, Johanna Lippman, Evelyne Braun, Marie-Paule Vallat, Patrick Miailhes,
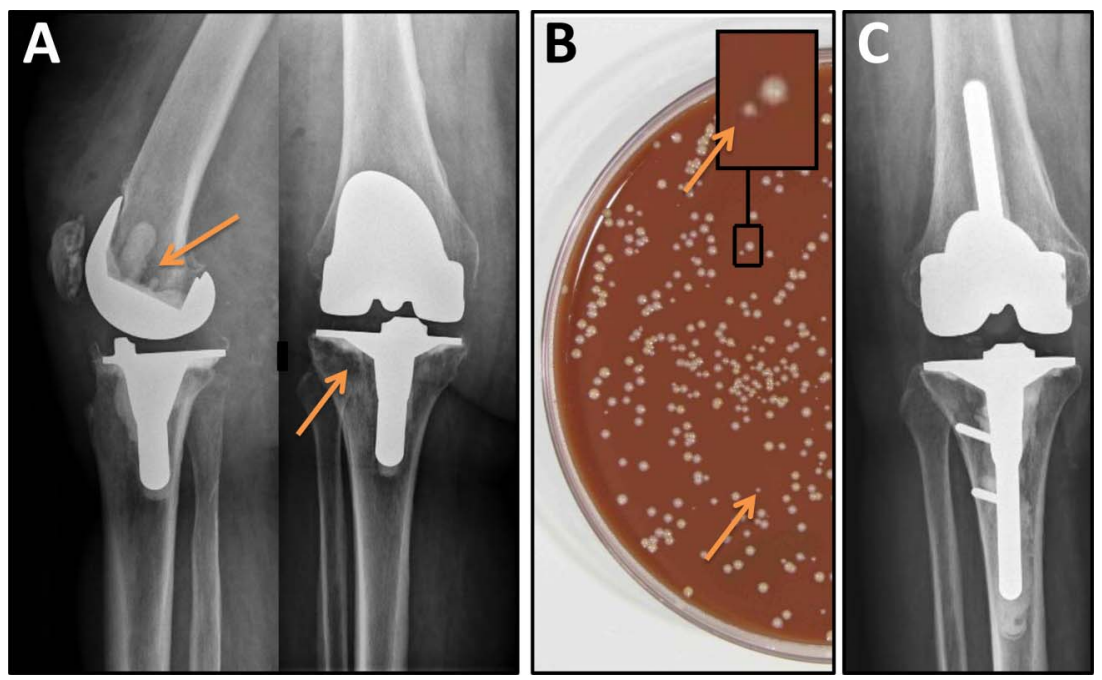

Figure 1 Periprosthetic pathological lucencies (A, arrows), associated with MSSA SCV in cultures (small colonies) obtained with sonication from prosthesis explantation ( $B$, arrows). After reimplantation and a total of 3 months of antimicrobial therapy, no relapse occurred at 1 year ( $C$, x-ray). 
Florent Valour, Christian Chidiac, Dominique Peyramond; Surgeons—Sébastien Lustig, Franck Trouillet, Philippe Neyret, Olivier Guyen, Gualter Vaz, Christophe Lienhart, Michel-Henry Fessy, Cédric Barrey; Microbiologists—Frederic Laurent, François Vandenesch, Jean-Philippe Rasigade; Nuclear Medicine —Isabelle Morelec, Emmanuel Deshayes, Marc Janier. Francesco Giammarile; PK/PD specialists-Michel Tod, Marie-Claude Gagnieu, Sylvain Goutelle; Clinical Research Assistant-Marion Martinez.

Competing interests None.

Patient consent Obtained.

Provenance and peer review Not commissioned; externally peer reviewed.

\section{REFERENCES}

1 Trampuz A, Piper KE, Jacobson MJ, et al. Sonication of removed hip and knee prostheses for diagnosis of infection. N Engl J Med 2007;357:654-63.

2 Proctor RA, Von Eiff C, Kahl BC, et al. Small colony variants: a pathogenic form of bacteria that facilitates persistent and recurrent infections. Nat Rev Microbiol 2006:4:295-305.

3 Osmon DR, Berbari EF, Berendt AR, et al. Diagnosis and management of prosthetic joint infection: clinical practice guidelines by the infectious diseases society of America. Clin Infect Dis 2013;56:e1-25.

Copyright 2013 BMJ Publishing Group. All rights reserved. For permission to reuse any of this content visit http://group.bmj.com/group/rights-licensing/permissions.

BMJ Case Report Fellows may re-use this article for personal use and teaching without any further permission.

Become a Fellow of BMJ Case Reports today and you can:

- Submit as many cases as you like

- Enjoy fast sympathetic peer review and rapid publication of accepted articles

- Access all the published articles

- Re-use any of the published material for personal use and teaching without further permission

For information on Institutional Fellowships contact consortiasales@bmjgroup.com

Visit casereports.bmj.com for more articles like this and to become a Fellow 